\title{
Concept of Lifelong Learning as an Indirect Factor in Preventing Crime and Reality in Kosovo
}

\section{Sc. Samedin Mehmeti (PhD Cand.)}

\author{
European University of Tirana, Albania \\ samedinmehmeti@yahoo.com
}

Doi:10.5901/ajis.2015.v4n1s2p215

\begin{abstract}
We live in the era of knowledge, and the ability to apply effectively knowledge and necessary skills, is a cornerstone of success for the individuals in relation to the challenges that they face. Where is put in doubt the power of learning and knowledge, there will reign darkness of ignorance. Lack of knowledge and skills is a disadvantage that prevents personal and career development as well as the professional advancement. Concept of lifelong learning is a dynamic system that enables integration in the labor market through the knowledge that an individual can achieve. This automatically means raising the level of academic and professional skills. The concept aims at acquiring knowledge for personal or professional reasons, by encouraging the system of ongoing, voluntary and self-motivated learning. The system as such influences: personal development, social inclusion, active citizenship, enables knowledge competition and increases employment opportunities. Competition in the knowledge and experience increase the quality and eminence. This concept enables the learning for all, and can be followed throughout life and in a variety of different situations. Learning can be seen as something that happens and its application can be included at all social strata regardless of age or gender. All these facts stated above have an effect in the lives of individuals who in most of the cases because of unawareness, inability to find a job because they are not qualified or been unable to engage actively in economic trends, but also loss of hope for the future, they engage in various forms of criminality in order to gain material benefits. This is also an argument more why this concept in the European Union, is an integral part of the policy of economic and social development which also serves as an instrument for ensuring social cohesion and development. But also is used as very important tool, indirectly to prevent individuals from involving in criminal activities as well as assisting law enforcement officers in education and training. Kosovar reality in this respect still leaves much to be desired. Learning in Kosovo is concentrated mainly in theoretical transfer of knowledge from teacher to the students and there are no proper mechanisms to convince that knowledge improved with appropriate skills and competencies will help individuals to be successful in implementation of knowledge earned. Formal system of vocational education and training is based on the provision of education and vocational training at elementary school and a continual professional training at institutions (training centers and employment centers). Universities mainly offer traditional academic lessons as well. The existing situation has a history of the past when Kosovars for ten years have held a parallel system of education. Despite the fact that the level and quality of service was not at satisfactory level, this period shows a reaction to restrictions imposed. Also this reaction through parallel system of education has manifested the Kosovar commitment to the values of education and training and the desire to learn. Despite many positive multiple reflections in the time of existence, this system has had its shortcomings and weaknesses which have its effects even to this day.
\end{abstract}

Keywords: Concept, Learning, System, Challenge, Competition

\section{Introduction}

The concept of lifelong learning is a system that enables dynamic integration in the labor market through the knowledge that man can achieve during his lifetime learning. This obviously means increased academic level but also development of professional skills.

Socio-economic revitalization of resources in the area where people live is highly important, because this manner of learning enables automation of human resource capacity. Improving performance of public administration as well as other employees in all institutions is providing services to the community through their training.

This concept that in Western Europe and North America, is known as "Lifelong Learning" or LLL, is a concept that aims to lifelong learning, voluntary and self-motivated. The knowledge acquisition is for personal or professional reasons. As such the concept of lifelong learning not only enhances social inclusion, active citizenship or concrete and personal development, but also enables competitiveness and employment.

Competition in knowledge increase the quality, this concept enables the learning to all, and can be followed 
throughout life and in a variety of different situations. Learning can be seen as something that happens and its application should include all social strata.

European Union (EU) has started this process a few years ago, 1996 was declared figuratively by EU as "the year of lifelong learning". Meeting of Ministers of Education of the Organization for Co-operation and Development (OECD) in January of that year used the slogan "make the concept of lifelong learning a reality for all". Report UNESCO in 1996 for the 21st century adopts "lifelong learning" as its core concept. ${ }^{1}$

\section{The Concept of Long Life Learning in General}

The concept of lifelong learning is set as a term or subject of educational and professional interest. Many countries are making efforts to implement the concept of lifelong learning in their schools. Today when we live in the era of internet and most people learn and get informed through the Internet. Is much easier to find different websites that write and given a host of information on the concept of lifelong learning. Also information regarding this concept are found at public information networks or in different newspapers. So the concept is publically well known.

Lifelong learning may be broadly defined as learning that is pursued throughout life: learning that is flexible, diverse and available at different times and in different places. Lifelong learning crosses sectors, promoting learning beyond traditional schooling and throughout adult life (ie post-compulsory education). ${ }^{2}$ Across Europe, North America and Australia a lot of associations, schools, colleges, institutes, but also universities already dutifully implement the concept of lifelong learning. The term "learning and lifelong learning" is encountered in studies and writings in English about 75 years ago, and many of the major contemporary ideas about "the concept of lifelong learning" are found immediately after World War II. Since 1970 this idea was the subject of a special care being discussed in a number of conferences and publications as calls for research and scientific studies.

We live in the era of knowledge, which means that the ability to apply relevant knowledge effectively is very important priority and the cornerstone of the success of the individual in relation to the challenges that he is faced with. Although some members had enrolled initially to meet other people, once they began attending they found that it was safe place to take intellectual and emotional risks. ${ }^{3}$ If anyone ever doubted the power of knowledge and learning he will notice the darkness of ignorance. For example, ask someone who has never used a computer to find a very simple article online. The learning and knowledge makes life interesting here gives life meaning.

Knowledge opens the windows and enables a bright perspective, enables people to debate various issues but also interesting conversations and with a deeper understanding. Knowledge makes people more suitable, enables them to make decisions fair and accepted from others, helps them to achieve success in their careers. The advancement of technology has increased the rhythm of the life in every day's life, and requires every day to learn something new that can remain coherent in the workplace.

In job training (or in-service training), at the companies where the individual works are very important for professional development. Of course that is a tool only for business where the worker is employed in the organization or company. However is not enough and is not to be counted only on the training that the company or organization provides, because they only offer professional trainings that is very important for the work but that's not replacing adequate education. It is useful for everyone to gain time to learn, to seek out their own opportunities, to use available resources wisely, and to find new sources. If you have decided to follow a particular course to learn and to apply it in your career, you should know of what to learn. When choosing a class or program, make sure you choose what you aim on your needs. Think about your current position and how you can progress on your position with training, program or course you prefer follow us.

Lack of knowledge is a disadvantage which inhibits people in their personal development but also in professional career advancements along. For this reason it is very important to keep in mind the permanent commitment to lifelong learning as a practice for self-improvement in continuity. Lifelong learning is an ongoing and exciting process. Because this form of education has become so important in our lives, various short and long courses have been developed to help those who stopped studying a while back or who simply want to learn something new. ${ }^{4}$ Without doubt, the lifelong

\footnotetext{
1 http://unesdoc.unesco.org/images/0010/001095/109590eo.pdf

2 http://www.Ilcq.org.au/01_cms/details.asp?ID=12

3 https://www.usm.maine.edu/olli/national/pdf/USM-What_Turns_Members_On.pdf

${ }^{4}$ https://www.gov.mt/en/Services-And-Information/Business Areas/Education\%20and\%20Learning/Pages/Lifelong-Learning.aspx 
learning is intellectual and spiritual refreshment but as well as filling with knowledge, and therefore this concept certainly helps: mind, body and soul. Lifelong learning involves two main aspects: review of different systems that include education, in order to create a society of lifelong learning and the concept of learning at all stages of life.

Lifelong learners have an inner desire to acquire knowledge in a broad range of subjects and disciplines. Thus the reward for lifelong learners is simply the joy of learning and acquiring knowledge in a wide spectrum of subjects that interest them. ${ }^{5}$ In other words, the concept of long life learning includes not only the structural learning through school and social education, but also learning through involvement in other areas of life that can also be knowledgeable about: sports, cultural activities, different hobbies, entertainment, including the voluntary activities.

Places for conducting learning activities are also varied, including almost all institutions where knowledge can be obtained, starting from: primary and secondary schools, colleges, various research institutes, universities and other institutions of higher education, training centers, citizens public halls, libraries, museums, cultural facilities, sport, specialized organizations for leadership of the program of lifelong learning in the private sector, organizations, companies, various offices etc.

\section{A Short Background of this Concept}

Lifelong learning was introduced for the first time on the international literature at the late sixties, originally appeared in various conferences about development of policies on different learning concepts and studies. The first to have promoted this concept in various forms were: Council of Europe, the Organization for Economic Cooperation and Development (OECD) and the United Nations Office for Education, Science and Culture (UNESCO). ${ }^{6}$

Periodical education should have had a very clear agenda and there were focused policies of the time. A test of this nature was initially was developed in Sweden, and then was distributed by the Center for Educational Research and Innovation (CERI) of the OECD. It was tested through a series of studies CER's project as an approach to formally dissolve lifelong learning whether by training, learning or employment and other activities.

This was an appropriate response to changing conditions and requirements for knowledge, or simply to use later expression just-in-case - the learning. The notion of education as a public good provided the basis in many countries for making 'free and compulsory' education available to all; proponents of education for a socially inclusive and democratic society now also claim lifelong learning as a public good (see Riche sin the Grass, Nordic Council of Ministers, 1995) We do not suggest that education, like other 'public goods' such as health and welfare services, requires no further financial investment from individuals and other sources; all such community services have to be supported financially and in a myriad other ways. But these services are vital and indispensable to the nature, quality and operation of the democratic society in which as citizens we all live and share in. ${ }^{7}$

Initially most of the discourse was focused in traditional education rather than lifelong learning. This concept could not be reached immediately, although UNESCO insisted and continued to promote broad as human use of this concept. The concept initially had its own difficulties in the application, however the concept enjoyed a remarkable revival in the nineties. During the seventies there were a certain number of policy studies which were mainly at national and other analyzes that emerged during this period was primarily concerned with periodic education. Mainly they do not include very successful attempts to develop an economic analysis of education. According to these studies the investment will return to the stage after completion of education.

Difficulties in economy and financial crises respectively in the eighties, connected to the individualistic approach especially in western societies, just being visionary and ambitious does not necessarily represent any perspective, simply was not enough.

This area was always problematic and confusion was present there, the best shows the OECD conference on lifelong learning and universities in the year 1998. The OECD's view was conceived explicitly as a strategy for the lifelong learning. While in the nineties, lifelong learning returned to public policy agenda.

The concept of lifelong learning appears strongly in the fifth World Conference on Adult Education organized by UNESCO in 1997,8 and the First World Conference on Higher Education organized by UNESCO in Paris 1988. ${ }^{9}$ This

\footnotetext{
${ }^{5}$ http://speeches.byu.edu/?act=viewitem\&id=1788

${ }^{6}$ Lengrand, P. 1975

${ }^{7}$ Aspin D. \& Chapman J, 2001

${ }^{8} \mathrm{http}: / /$ www.unesco.org/bpi/eng/confintea/
} 
concept also reaffirmed as one of the principles of organization of tertiary education. OECD has made a number of publications on this topic and has performed a very important mandate for education in the period 2002-2006.

\section{Skills and Opportunities Offered by the Concept of Lifelong Learning}

It is a large number of factors affecting the findings and that directly affect the development of this concept. Undoubtedly, technological developments, especially globalization, and changes in labor market demand and impose the recognition of new techniques to perform duties.

Key skills acquired by the concept of life-long learning are a combination of knowledge, skills and appropriate attitudes. They are particularly necessary for the fulfillment of personal needs and development, social inclusion, participation in active citizenship but of course in career development and employment. Key skills are essential in a knowledge society and guarantee more flexibility in the labor force, enabling individuals to quickly adapt to constant changes in social development. The acquisition of skills is also a very important factor that influences creativity, productivity and competitiveness, and at the same time contributes to motivation and providing a sense of satisfaction than employees, but also in raising the quality of work. There are two main reasons for learning throughout life: for personal development and for professional development. These reasons may not necessarily be distinct as personal development can improve your employment opportunities and professional development can enable personal growth. 10 These skills make individuals to have more opportunities to find work and that simultaneously affects the fact that they have less space and reason to get involved in criminal activities.

\section{Some of the Factors Affecting Involvment in the Criminal Activities}

Criminality is a social phenomenon which has existed since the beginning of the existence of humanity. In different periods of social and community development were different forms crime. Criminal activities and various forms of crime in history had the characteristics of economic system, political and legal environment in which they were present. Therefore the factors affecting the appearance of criminal phenomena are similar to social developments which were present at the time of appearance of the criminal acts.

Among many factors that influence and encourage individuals especially youth and minors in involvement in crime are social factors that relate directly to education and schooling. Incentives of criminal behavior among minors and young people, about the impact of school and community are as important as other factors. Young people have a certain connection with school, and have an interest and love it, confirmed with the norms and values that promote school.

Studies on the school impact to anti-social behavior have shown that consistently poor performance in school is directly or indirectly related to the behavior of children, as well as incidence and emergence of criminality in early ages. Fragile links with school, little desire for education, low educational aspirations, and the low level of motivation bring the child in extremely vulnerable conditions to engage in criminal activities. ${ }^{11}$

Everywhere in today's world from individuals is required knowledge, professionalism and greater capacity. Many of the occupations and crafts performed were learned while observing or being trained by professionals of respective fields. One of the opportunities to be trained and professionalized is the training or education in vocational schools, and that is a way which provides greater opportunity in finding a job. Having a job affects individuals to have less time, willingness and ability to get involved in criminal activities. Parents want their children to attend school and succeed in this regard. Possibility of children for success in school is not exclusively genetic but major role is played by the influence that comes from education and schooling system, depends on how children are accommodated to the school environment. Parents have a great impact on their children in which way in the future these children will fit to the schooling and educational system.

\section{Prevention, Combating Crime and the Role of Lifelong Learning}

Preventing and combating crime is a fundamental principle in all democratic societies, that's intended to guarantee

\footnotetext{
${ }^{9}$ http://www.unesco.org/education/educprog/wche/diaz-e.htm

10 http://www.skillsyouneed.com/ps/lifelong-learning.html

11 UNICEF, 2007.
} 
freedom and human rights. Authorities in the fight against crime should have different strategies in preventing and combating crime, ranging from the safety of individuals and property, facing the economic and social crises, particularly unemployment and other phenomena.

Fight against crime requires that personnel employed on law enforcement agencies are trained and professional, active, prepared and able to provide with necessary information every time. This information should be served in a way to have a positive impact on the public as to inform the public about risk and the types of damages that criminality brings with. Also they should be able to explain to the public what steps were taken and how much success is achieved in preventing and combating crime. Public should be systematically informed and "educated" about the fact that facing crime is joint action, where law enforcement agencies have their leaderships responsibility, but they are not alone, because in the end security is a concern to all. Proactive role of law enforcement agencies with public could lead to better cooperation, to gain important information in order to increase confidence in the agencies. This is achieved only through professionally prepared and well-trained staff, this is best achieved through permanent education and learning.

Cooperation of the authorities should be extended to other factors such as the science and academic studies. Of particular importance are the academic studies and staff who are engaged in technical and technological sciences, because scientific achievements and innovations, helps in achievement of good results in dealing with crime.

There is always a need to gain knowledge about the exchange of operational information on the movements, contacts and activities of criminal groups locally and internationally. It is a topic that should be studied, professional learning and permanent preparedness of officers of these agencies is necessary. International cooperation between different agencies in order to combat crime should be reflected not only through the exchange of operational information's on time, but also by applying special investigative techniques, a segment that is further needed almost in every criminal investigation for the purpose of proving the activities of criminal groups. In this regard, international cooperation is a logical continuation of operational measures and actions taken at the national level. The possibility of tracking and detection of the inductions and sigs on criminal activities depends largely on the ability of law enforcement officers to detect, interpret, document and disseminate such information to the department responsible for combating this form of crime.

Without properly trained officers, our society could not successfully function. Law enforcement officers must be trained extensively in federal and state law, evidence handling, prisoner transport, handcuffing, defensive tactics, firearms, driving, customer service and many other areas of law enforcement. ${ }^{12}$ For example how much education and specialized training is needed to gain sufficient knowledge to investigate various crimes as robbery, extortion, kidnapping, illegal trafficking, corruption etc. For the successful investigation and clarification of these criminal activities, which are not known initially to be carried out by individuals or groups and criminal organizations, law enforcement officers should be professionally prepared to identify signs or indications which show who may be the perpetrator. These signs may be different: facilities, data and documents found during the search of premises and persons etc. Namely the founded objects, indications mentioned above do not always show together directly, but is required further analysis and operational work as well as liaison with other circumstantial evidences collected to determine how and what connects this evidence with suspects.

A very important factor in crime prevention is effective prosecutorial and judicial system.

Criminal justice system by no means operates in a vacuum. Appreciation of how the system can drastically change, sometimes in the matter of a single day, helps us understand the dynamic and vulnerable nature of criminal justice employment. ${ }^{13}$ Education of staff is only one part of the solution. Changes in legislation and different techniques and methods of committing criminal acts are just some of the elements that should be carefully monitored by law enforcement agencies, in order to succeed in dealing with crime. The best way to achieve successes is the permanent learning throughout life, either through education or vocational training which will help in learning and updating the knowledge about the problems of this nature.

\section{References}

Aspin D. \& Chapman J. "Paper presented at SCUTREA, 31st Annual Conference, 3-5 July 2001, University of East London" UK, London 2001.

12 http://policelink.monster.com/training/articles/143993-the-history-and-importance-of-police-training

13 file:///C:/Users/Refresh/Downloads/04_schm5e_Hist_Dev_CJ_Employmt.pdf 
"Longlife Learning Council Quinsland inc", accessed 12. 01.2015 http: //www. Ilcq. org. au/01_cms/details. asp?ID=12

"Goverment of Malta- Lifelong Learning", accessed 12. 01. 2015

https: //www. gov. mt/en/Services-And-Information/Business-Areas/Education\%20and\%20Learning/Pages/Lifelong-Learning. aspx

"The Criminal Justice workforce- Historical Developments in Criminal Justice Employment" accessed 01. 02. 2015 file: I//C: Users/Refresh/Downloads/04_schm5e_Hist_Dev_CJ_Employmt. pdf

Lengrand, P. "An Introduction to Lifelong Education", London: Croom Helm, and UNESCO, Paris, 1975.

"Skills you need- Lifelong Learning" accessed 27. 01. 2015, http: //www. skillsyouneed. com/ps/lifelong-learning. html

"Police link- The History and Importance of Police Training" accessed 02. 02. 2015

http: //policelink. monster. com/training/articles/143993-the-history-and-importance-of-police-training

"University of Southern Maine-PARTICIPATION IN LIFELONG LEARNING INSTITUTES: WHAT TURNS MEMBERS ON?" accessed 13. 01. 2015, https: //www. usm. maine. edu/olli/national/pdf/USM-What_Turns_Members_On. pdf

"Birgham Young University - The Journey of Lifelong Learning " accessed 14. 01. 2015, http: //speeches.byu.edu/?act=viewitem \&id $=1788$

"UNESCO - Report to UNESCO of the International Commission on Education for the Twenty -first Century" accessed 05. 02.2015 http: //unesdoc. unesco. org/images/0010/001095/109590eo. pdf

"UNESCO- 5th INTERNATIONAL CONFERENCE ON ADULT EDUCATION 14-18 July 1997 in Hamburg, Germany" accessed 26. 01. 2015 http: //www. unesco. org/bpi/eng/confintea/

"UNESCO- World Conference on Higher Education: Vision and Action-Paris 1998. accessed 26. 01. 2015

http: //www. unesco. org/education/educprog/wche/diaz-e. htm

UNICEF, "Kriminaliteti i te miturve ne Shqiperi- Analizë e shkaqeve dhe faktorëve të kriminalitetit tek të miturit në Shqipëri", Albania, Tiarana, 2007. 